ESJ Social Sciences

\title{
Perceptions and Experiences of Change in Practices of Masculinity among University-Educated Men of Iranian Origin in Quebec
}

\author{
Zohreh Mehdizadeh, (PhD in Sociology) \\ Université Laval/Quebec, Canada
}

Doi:10.19044/esj.2021.v17n19p22

Submitted: 14 April 2021

Accepted: 29 May 2021

Published: 30 June 2021

\author{
Copyright 2021 Author(s) \\ Under Creative Commons BY-NC-ND \\ 4.0 OPEN ACCESS
}

Cite As:

Mehdizadeh Z. (2021). Perceptions and Experiences of Change in Practices of Masculinity among University-Educated Men of Iranian Origin in Quebec.

European Scientific Journal, ESJ, 17(19), 22. https://doi.org/10.19044/esj.2021.v17n19p22

\begin{abstract}
Through 19 qualitative interviews with university-educated men of Iranian origin living in the province of Quebec, this article sets out to examine their perceptions and experiences of performing masculinity in a new social setting. The Life Course theoretical approach has been applied to analyze how a shift in the social, cultural, and family context run by different ideals of manhood impacts the practices through which men expressed their masculinity. Thematic and comprehensive analyses of the data revealed gender roles apportioned to men in the society of origin, conjugality, and legal standards of the host society to be the main domains where changes and challenges were experienced. The results help us understand that masculinity, like femininity, is a contextually situated trajectory constructed in an ongoing interaction between the larger social structures and individual agency; like any other pathways of individuals' lives, masculinity is a continuous process of rethinking and reinventing certain configurations, including the gender relevant attitudes and behaviors establishing what manhood is about and how it should be in a given societal context (Carpenter, 2010; West \& Zimmerman, 1987). Masculinity is also a situated act as it evolves in a sociocultural context that has already defined some expressions of gender identities as ideal (West \& Zimmerman, 1987).
\end{abstract}

Keywords: Masculinity, Immigration, Marital dynamics 


\section{Introduction}

Changes in Canada's immigration policies since 1960 and the introduction of a point system for selecting immigrants has contributed to a shift in migratory tendencies, from a predominantly European immigration source to one coming primarily from Asian countries. The newcomers of European origins that once accounted for $61.6 \%$ of total immigrants admitted in 1971, represented just $11.6 \%$ of those who arrived in 2016. Instead, there has been a rise in immigration from Asian and the Middle Eastern countries, especially from the Philippines, India, China, Iran, Pakistan, Syria and South Korea, constituting 61.8\% of recent immigrants to Canada between 2011 to 2016 (Statistic Canada, 2017). This raises the question as to what we know about the post-migratory experiences of these groups while adjusting to the new social context. As many of these recent immigrants come from Asian countries, usually maintaining traditional conceptions on gender, one may wonder how masculinity or femininity will be performed when faced with new social standards on gender-relevant roles and behaviors. Immigration has been identified as a gendered process, with men and women of the same family experiencing differently their encounters with the social structures of their new setting (Farahani, 2012). Many aspects of family arrangements may go through changes, including how femininity or masculinity are performed, and thus leading to changes in the ways interpersonal relations are organized between members (Farahani, 2012; Hondagneu-Sotelo, 1992).

The domains of family that seem to be understudied among immigrant families of ethnic origins in Canada are their gender trajectory, particularly for men and masculinity (Farahani, 2012; Khosravi, 2009). Using semi-structured interviews with 19 immigrant men of Iranian origin living in greater Montreal and Quebec City, this qualitative study intends to shed light on their perceptions and experiences of change in performing masculinity. Studying men- who are usually in a dominant cultural position- is not contributing to strengthening the inequalities women have been subjected to in most parts of the world or stepping away from "feminist projects." On the contrary, it should be understood "as a complementary endeavor, indeed one that is organically linked" (Sinclair-Webb, 2006, p. 8). The fact is that most literature examining gender-related experiences of Iranians in diaspora have been conducted among women (Farahani, 2012; Khosravi, 2009). Questions remain as to how masculinity is perceived or performed when men are faced with new genderrelevant schemas following immigration. Departing from this lapse in the research on immigrants of Iranian origin, the central questions this paper seeks to answer are: (a) What are the post-migratory changes experienced by men in their practices of masculinity?; and, (b) How do these changes affect their marital dynamics? To answer these questions, this qualitative study draws on the life course theoretical perspective. The focal point of the life course 
approach is that life trajectories, including gender, are situated phenomena, formed in an ongoing interaction between two key factors: social and biographical context (Elder, 1985; Elder, Johnson, \& Crosnoe, 2003; Furstenberg, 2003; Macmillan \& Copher, 2005; Mayer, 2004; Thomas \& Znaniecki, 1984). Immigration means that the interplay between the biographical context and societal structures are transferred to a setting run by different sociohistorical circumstances. The effects of this transition may be experienced on multiple levels, including in their gender trajectory (Farahani, 2012; Khosravi, 2009).

This article begins with outlining the theoretical directions used to conduct the study. A description of the methodology is provided afterwards. The paper concludes by presenting the results, followed by closing discussions.

\section{Framework}

This study is structured within the life course analytical perspective. Life course refers to an ensemble of trajectories (such as family, educational, professional, residential). Trajectories consist of roles, attitudes, behaviors, movements, events, and transitions that are socially situated phenomena (Elder et al., 2003). In carving out their pathways, individuals are usually inspired by the directives that social institutions provide them with. These social scripts are used as guidelines, exempting people from defining new situations that may emerge along the developmental path of their trajectories. They are socially defined and transferred through the institutions of family, work, or education (Elder et al., 2003; Furstenberg, 2003; Gaudet, 2013; Macmillan \& Copher, 2005; Mayer, 2004; Thomas \& Znaniecki, 1984). Embedded in larger social structures, life trajectories of individuals reflect to some extent the cultural meanings attached to certain ways of doing and thinking (Furstenberg, 2003; Macmillan \& Copher, 2005). However, this does not imply that people are passive receivers of social scripts. On the contrary, they are actively involved in the development of their life course, the latter taking place in an interactive process between the context (social, cultural, institutional) and the agency that social subjects exercise in making choices. The latter usually manifest itself in, among other things, selecting some social directives, resisting others, and thinking about certain ways of being and doing (Carpenter, 2010; Elder et al., 2003; Gaudet, 2013; Macmillan \& Copher, 2005; Mayer, 2003).

The current study is focused on gender trajectories. Gender as a life trajectory has been recently a subject of study from the life course perspective (Carpenter, 2010). It is a trajectory because "doing gender" is an ongoing process of working on one's identity (Carpenter, 2010; West \& Zimmerman, 1987). West and Zimmerman (1987) reject any idea of gender as solely an 
ensemble of "roles" or "traits." On the contrary, gender is a dynamic ensemble of performances, an act that takes place within the constraints set by the socioeconomic, political, and cultural contexts in which lives are entrenched. It is a "doing" within a structural context that has already defined a certain model of womanhood or manhood as the ideal and natural ways of one's male or female identity. More precisely, gender "is the activity of managing situated conduct in light of normative conceptions of attitudes and activities appropriate for one's sex category" (West \& Zimmerman, 1987, p.127).

Life course trajectories, including gender, are characterized by continuity and stability. However, changes are encountered at some stage along the pathway. Defined as transition, it could be a change in roles, status, or social setting. Some transitions could be a turning point for individuals living the phenomenon, in the sense that they alter the daily routine of the affected trajectory, reorienting them into constructing new ones (Elder et al., 2003; Gaudet, 2013; Gherghel, 2013; Mayer, 2004). Immigration has been defined as a transition (Gherghel \& Saint-Jacques, 2011). Individuals' life course being a situated phenomenon, a move in social setting means changes in contextual scripts guiding the unfolding of pathways (Elder et al., 2003; Thomas \& Znaniecki, 1984). It changes the context of dialogue between social structures and gender identity (Khosravi, 2009). Performing masculinity and femininity cannot continue unchanged. As for masculinity, Connell (2005) defines it as a position along a gender trajectory that men try to situate themselves into through a set of practices. Like other social identities, masculinity involves an ensemble of social arrangements that are embedded in time and space (Connell, 2005). Consequently, immigration may cause a transition in the gender trajectory of men in terms of the ways masculinity is performed (Khosravi, 2009).

\section{Methods}

This qualitative study is based on thematic and comprehensive analysis of 19 life stories (récits de vie), collected through interviews with universityeducated men of Iranian origin living in the Province of Quebec. Life stories are a commonly applied technique for data collection in qualitative studies. They provide researchers with effective tools for gathering information on individuals' subjective and objective experiences of different social phenomenon, according to Bertaux (2005). Through life story interviews, centered on the ways of doing gender among immigrants of Iranian origin residing in Quebec, this article aims at exploring their perceptions and experiences of changes in their roles as man and husband following immigration to Quebec. Semi-structured interviews were chosen to conduct all the interviews. However, interviews were restructured where needed, for instance when gathering information on respondent's social backgrounds. 
Questions were structured around several major themes generated by the research questions and its objectives: roles and responsibilities of man and woman in family, transition in roles, expressions of masculinity and femininity in both society of origin and the host country, gender split of tasks, decision of immigration, challenges encountered as a couple in the migratory context, difficulties experienced in the job market, and changes introduced in couple's relations since their arrival in Quebec. 
Table 1. Characteristics of participants*

\begin{tabular}{|c|c|c|c|c|c|c|c|c|c|}
\hline Pseudonym & Age & $\begin{array}{l}\text { Matrimoni } \\
\text { al Status }\end{array}$ & $\begin{array}{l}\text { Category of } \\
\text { immigration }\end{array}$ & $\begin{array}{l}\text { Arrival } \\
\text { year }\end{array}$ & City & $\begin{array}{l}\text { Education before } \\
\text { immigration }\end{array}$ & $\begin{array}{l}\text { Education } \\
\text { after } \\
\text { immigrati } \\
\text { on }\end{array}$ & $\begin{array}{l}\text { Occupation } \\
\text { before } \\
\text { immigration }\end{array}$ & Present occupation \\
\hline Mansoor & 38 & Married & Skilled worker & 2010 & Montreal & Masters & Bachelors & Architect & Dentist \\
\hline Said & 36 & Married & Skilled worker & 2014 & Montreal & Masters & Masters & $\begin{array}{l}\text { Legal } \\
\text { Consultant }\end{array}$ & Unemployed \\
\hline Arsya & 33 & Married & Work permit & 2016 & Montreal & Post doctorate & ----------- & $\begin{array}{l}\text { Postdoctoral } \\
\text { researcher }\end{array}$ & $\begin{array}{l}\text { Postdoctoral } \\
\text { researcher }\end{array}$ \\
\hline Amin & 40 & Married & $\begin{array}{l}\text { Family } \\
\text { reunification }\end{array}$ & 2012 & Laval & Associate degree & ----------- & $\begin{array}{l}\text { Dental } \\
\text { technician }\end{array}$ & Dental technician \\
\hline Moein & 36 & Married & Skilled worker & 2017 & Montreal & $\mathrm{PhD}$ & Masters & $\begin{array}{l}\text { Oil contracts } \\
\text { consultant }\end{array}$ & Student \\
\hline Alireza & 41 & Separated & Skilled worker & 2011 & Montreal & Bachelors & ---------- & Export director & Unemployed \\
\hline Khosro & 43 & Married & Skilled worker & 2014 & Montreal & Masters & ---------- & Journalist & $\begin{array}{l}\text { Art/Video } \\
\text { specialist }\end{array}$ \\
\hline Arya & 37 & Married & Skilled worker & 2015 & Montreal & Bachelors & ---------- & Engineer & Unemployed \\
\hline Mazyar & 38 & Separated & Skilled worker & 2015 & Montreal & $\begin{array}{l}\text { Associated } \\
\text { degree }\end{array}$ & ---------- & Project director & Self-employed \\
\hline Hadi & 40 & Separated & Skilled worker & 2015 & Montreal & Masters & ---------- & Engineer & Writer \\
\hline
\end{tabular}


European Scientific Journal, ESJ

ISSN: 1857-7881 (Print) e - ISSN 1857-7431

June 2021 edition Vol.17, No.19

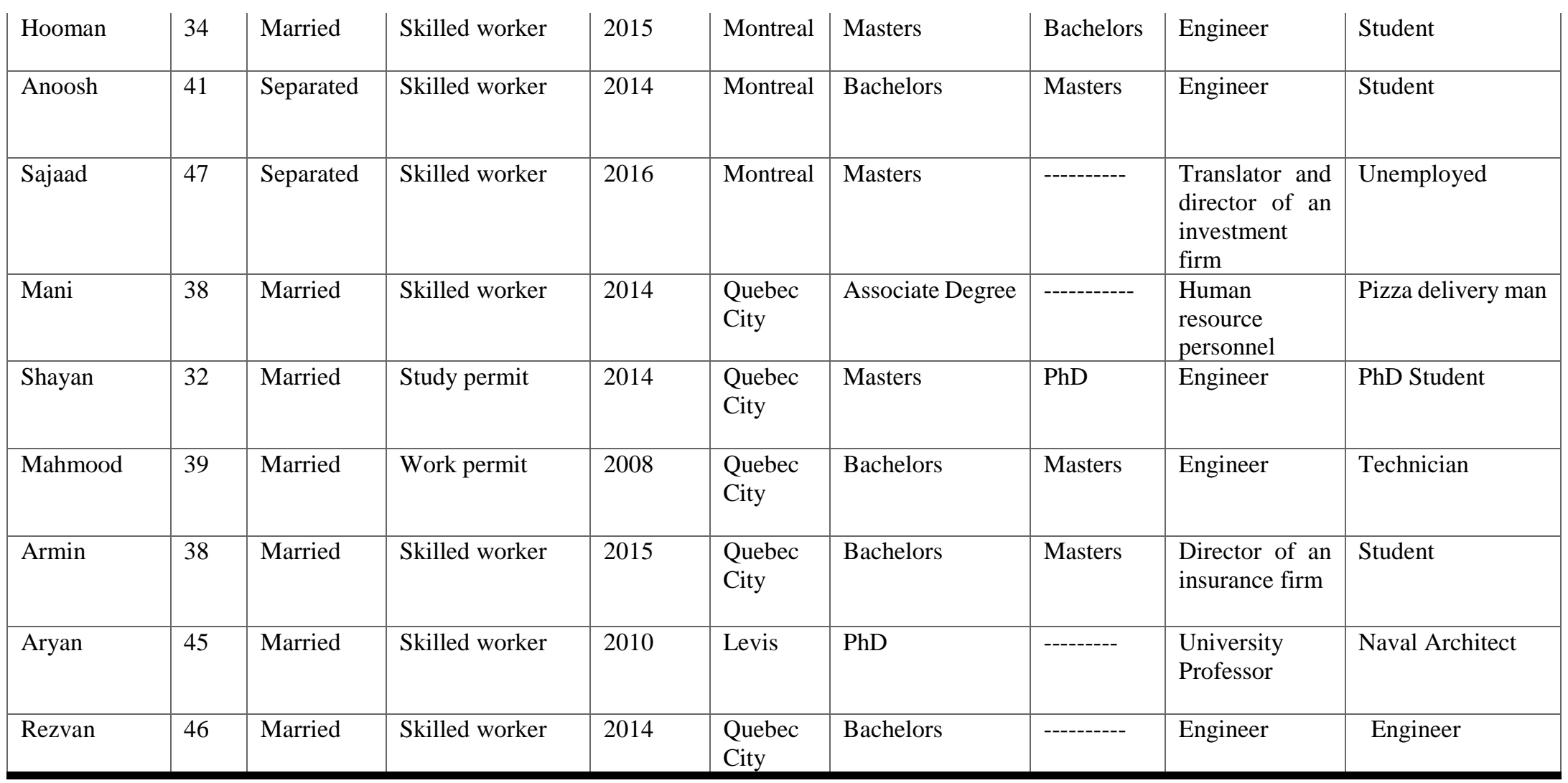

*Presentation based on the chronological time of interviews. 


\section{Participants}

Participants were recruited through the social media accounts of Iranians living in the province of Quebec, mainly through Facebook (Infos pratiques sur Montréal, Les Iraniens à Québec) and Telegram pages. Some were also recruited through the researchers' personal contacts with the Iranian community. The snowball sampling technique also proved to be a fruitful strategy, providing the researcher with some additional research participants. With the consent of all participants, interviews were recorded and then transcribed. All interviews were conducted in Persian. In fact, the participants were asked whether they preferred to be interviewed in Persian, French, or English. All chose Persian, their mother tongue, feeling more comfortable to express themselves in that language. The meetings were preceded by a brief presentation of the project, its objectives, and the signing of consent forms. Most of the participants were interviewed in public places, such as coffee shops, and libraries. Two of them preferred to have the meetings at their home. In total, 19 men were interviewed, including 13 in the greater Montreal area and 6 in the metropolitan area of Quebec City. This uneven proportion was not deliberately sought. Indeed, this is not particularly surprising given that Montreal itself is the main place of residence for $77.1 \%$ of the Iranians in Quebec, who numbered 25,535 individuals in 2016, according to data provided by Ministère de l'Immigration, de la Francisation et de l'Intégration (MIFI, 2019). The participants in this sample were aged between 32 and 47, with a median age of 39 years. Of all the 19 respondents recruited for this study, 14 were living with a partner, and 5 were separated at the time of the interview. The majority, 15 of them, came to Quebec on an economic plan of immigration; one was admitted under the family reunion program; one came with a study permit; and another one came as a post doctorate researcher. The sample also had a participant who came to Quebec with a temporary work permit to accompany his wife who was doing her $\mathrm{PhD}$ in the province. While one of the participants had settled in Quebec in 2008, all others arrived between 2010 and 2017. 52.6\% of the respondents had more than 17 years of education before immigration, which is 10 out of 19 individuals. More precisely, seven participants held a master's degree, two of them had a doctorate, and another one had started a second post-doctorate. Six participants held a bachelors degree as the highest level of their education, while three others had associate degrees. Out of 19 interviews, only seven participants had jobs related to their expertise or training; four of them were unemployed, one had a general job as a pizza delivery man, another one was self-employed, one man was working as a writer with temporary source of revenue, and four of them had gone back to school. 


\section{Data analysis}

Thematic and comprehensive methods were used to analyze the data. Paillé and Mucchielli (2008) define "themes" as the words or phrases reflecting the apparent or latent meanings conveyed through participants' words, feelings, and thoughts. Taken directly from their testimonies or constructed by the researcher but faithfully reflecting the content of respondents' information, themes provide researchers with tools to adequately answer the research questions. The thematic analysis- as pointed out by Paillé and Mucchielli- has two major objectives: identifying themes, then documenting them. The first one highlights the process of generating codes, then thematizing the encoded data, while the latter involves regrouping themes in relation to their resemblance and differences before proceeding to prioritizing the clusters of themes based on their importance. The latter is determined in accordance with the recurrences of themes and the relevance of their information to the subject being investigated. Departing from thematic analysis developed by Paillé and Mucchielli (2008) as well as by Nowell, Norris, White and Moules (2017), this paper resorts to a hybrid form, combining deductive and inductive thematic coding; the former combines an ensemble of predefined themes taken from the theoretical and conceptual directions of life course theory as well as from research conducted on similar subjects. New themes were also constructed inductively all along the coding process. After themes were identified, they were subsequently grouped according to their affinities under a heading, the latter referring to the common pattern discerned between them. The thematic schemas were supported by direct quotations from respondents to illustrate their content more profoundly, as suggested by Nowell et al. (2017). To interpret themes and explain the social mechanisms they conveyed, the comprehensive model of Kaufmann (2016) was adopted in this article. The interpretative step is an important phase of the qualitative study. In fact, the production of sociological knowledge is to a great extent the outcome of such explanatory moments aimed at understanding and interpreting respondents' knowledge about the research phenomena, and their experiences in this matter. Theory, analytical concepts, and comparing the results with those of other studies -as proposed by Kaufmann- were used to verify the validity of the analysis. Kaufmann states that there will always be the risk of subjectivism in such mode of analysis. However, the force of the latter could be mitigated by researchers' control over their preconceptions and distance from their personal views regarding the interviewee and the subject of the study.

\section{Findings}

Findings will be discussed around four major themes: provider, protector, conjugality, and masculinity at a disadvantage. The themes will 
address experiences of post-migratory changes in practices of masculinity. Some elements of the new social settings that participants in this study believed had emasculating consequences on their position as a man or husband will also be introduced.

\section{Provider}

In Iranian society, manhood is closely tied with adequately fulfilling the role of a provider. Men growing up with this cultural perception on masculinity may encompass it as part of their masculine identity (Mahdi, 1999). When asked about practices of masculinity in Iran, most participants reported that providing for family was significant and essential in being viewed as a good and respected man and husband. One respondent asserted:

...In the Iranian society, there is a lot that is expected of men.

Some chores are specifically for men to do, such as financially supporting the family. And if they fail to do so, they lose face in the society.... (Arsya)

As for women in Iran, they are not socially viewed as responsible for the family's economic upkeep. This point was echoed in most participants' accounts of running their family finances. In fact, all men interviewed for this study were university-educated who used to have well-paid jobs before immigration. Apart from one participant, all were married to well-educated women, some of whom were also building careers. However, their wives were not considered as the provider of the family, neither by their husbands nor their family. This approach to women's economic contribution is embedded in a social context that labels as "powerless head" a man who may depend on his wife's work or who is outearned by his partner, representing him "as a castrated chief (akhte)" (Hojat, Shapurian, Foroughi, Nayerahmadi, Farzaneh, Shafieyan, \& Parsi, 2000, p. 431). Thus, it is not surprising that most men in this research perceived securing the financial well-being of the family as an indispensable male role. One of them commented:

I believe the greatest role of a man is the financial role that he assumes. The way I learned it from my own family, moms oversee rearing children and their education; dads are in charge of running the financial affairs of the family, usually not involved in their children's education.... (Said)

Transition to a new social setting following immigration means a shift in situated practices of masculinity. For some immigrants, a geographical move could turn into an opportunity to renegotiate and redefine some aspects thus far essential for their gender identity (Farahani, 2012; Khosravi, 2009; Shahidian, 1999). Providing for the family is one of the areas prone to change 
(Mahdi, 1999). The widely held, culturally rooted, conception of man being responsible for the material needs of the family decreases in importance in a society such as Quebec where the traditional binary model of "mereménagère" and "père-pourvoyeur" designating men and women with rigid conventional gendered roles has been replaced since 1960 by shared family responsibility (Dandurand, 1994). Faced with new social scripts on gender roles, participants in this study -apart from two of them-mentioned that they were amenable to such change. And this was mostly because it was perceived as less economic responsibility, hence less stress for them:

There is a great deal of social security here for both men and women, even for immigrant men. If immigrants could adapt themselves to such an atmosphere, they will have more security. I mean social security for men. The daily pressures on men in Iran do not even allow them to cry. They are constantly reminded of what they should do and what they cannot do... Men have heavy responsibilities in Iran... Because of social equality attributed to both men and women here in Quebec, men have lesser responsibilities such as economic roles. So, they could breathe here. (Arya)

Despite showing resilience towards changes in their role as a provider following their immigration to Quebec, participants explained that they still did not expect their wives to be concerned with family finances, because providing for the family's livelihood was a man's job rather than being a woman's responsibility:

...It could be because of my experiences in Iran that I consider myself to be responsible for my family's economic situation. I believe that if my family needs something or if our financial situation is not good enough, I am the one who should take care of it. I do not expect my wife to be responsible for such needs. When talking about equality, I believe it should exist. But, when it comes to outside home, I think my responsibility is heavier... (Mansoor)

Only one man expressed that he did not consider providing for the family as a unilateral male job anymore, and that women should contribute as well if working:

I have a preference now. Before, I only knew one model but since we came here, I have known two. I cannot accept anymore that my wife works and does not expend her revenue for household 
expenses. She cannot expect me to be the only one providing for family while she is working too... (Alireza)

Of the two men resisting women sharing economic responsibility with them, one indicated that "man has a kind of power that means he must work and support others; not be supported. It won't fly that a man be dependent on his wife; and consequently, hold a lower status than her" (Anoosh). The other preferred himself as the primary wage earner because "... providing financially for the family is a man's responsibility, not a woman's. A woman's work outside home means sacrificing herself and her family..." (Said). Such a stand on women's professional activities is mostly related to the authority that comes with men overseeing family finances and resources. This monopoly could be threatened by women's economic autonomy, the one associated with boosting their social status (Darvishpour, 2002; KianThiébaut, 2005), and likely to initiate change in marital power dynamics (Darvishpour, 2002). Usually, immigration means a transition in "traditional bases of men's authority", including them being defined as primarily responsible for the family's economic upkeep (Mahdi, 1999, p.61). Difficulties met by immigrants -particularly immigrant men from nonEuropean sources of immigration- in Canadian labor market have been well documented. De-professionalization, the lengthy process of assessing their international credentials and work experience, the lack of work-specific language skills, and racial discrimination have been identified as the main obstacles to a successful professional integration of immigrants in the shortterm (Boudarbat \& Grenier, 2014; Boulet \& Boudarbat, 2015; Cousineux \& Boudarbat, 2009). The financial instability caused by an uncertain professional future could negatively impact immigrant men's self-esteem and increase the stress experienced while going through the adjustment to the new social setting (Kennedy \& McDonald, 2006). As in these studies, some of the men interviewed for this study expressed that the challenges of the labor market since their arrival in Quebec had spawned negative implications on their self-confidence and marital relations. Difficulties in entering the qualified labor force had obliged five of them to return to their studies to get Canadian credentials, and others to take courses or training programs. For these men, immigration had created a turning point along their professional trajectories, since they had to reorganize it or start a new one so that it could meet the standards of the labor market in the host society. Some had to accept unqualified jobs, others lived on government financial aid. Only two men could find a relevant job to their area of expertise a few months after they settled in Quebec. They all described it as a stressful situation, mainly because their social status had decreased following this shift in their professional path. 
Consequently, some of them had started to question their decisions to immigrate:

I used to have a much more prestigious job back in Iran... Then, I came here and turned into an unskilled worker. It is and has been excruciatingly unbearable. It has created a huge paradox in my mind as to whether it was worth it at all to leave an opportunity behind and come here and start from scratch... (Mani)

As for the impacts of precarious professional and financial situation on marital life, only one respondent believed that not being able to adequately provide for family was the main element making his ex-wife dissatisfied with their marriage, thus leading to separation. Others perceived it as a stressor for themselves and their wives, negatively influencing their self-esteem and sometimes causing dispute in their relationships. This was mainly noticed among respondents performing unqualified jobs. Jobs below their level of expertise, poorly paid jobs, and long shifts were mentioned as factors negatively impacting their family relations. One man voiced the following:

The job opportunities I had here left negative impacts on me and my family life. I must work longer hours and spend less time at home. I am tired most of the time and do not spend enough time with my family. I have done my best so it would not affect my relationship with my child but some of it is inescapable. (Mani)

\section{Protector}

Achieving their role as family protector is another defining aspect of manhood in Iranian society (Khosravi, 2009; Shahidian, 1999). It usually involves men assuring the moral behaviors of family members, particularly women. The authority that comes with it allows men to control women's activities. The following quote illustrates this point:

...I have no idea how it would be possible for me not to know where my wife is for a whole day, or how we can have two separate cars, one of which she can take and drive off on her own, all independent. If I knew this were a possibility I would never get married ....(Said)

The protector role was challenged in the Quebecois society, which is guided by ideals of equality between both sexes and individual autonomy. In prior research on Iranian families living the migratory phenomenon (Darvishpour, 2002; Khosravi, 2009; Moghissi, 1999; Moghissi \& Goodman, 1999; Shahidian, 1999), a few changes have been singled out as key elements diminishing men's traditionally defined role as the protector. Among these, the most influential ones are the decrease in male professional status while 
women experience an increase in their occupational activities. Though many women experience challenges in the labor market too, immigration for most Iranian women -as noted by these studies- generally means access to better professional opportunities than before, to more governmental financial aid and to better social rights. Gaining usually more social and economic autonomy than they used to have before immigration, Iranian women may develop more assertiveness about their aspirations and expectations of marital relations. Similar to the findings of these studies examining the impacts of immigration on marital dynamics of Iranians in diaspora, the social and economic independence achieved by women appeared to have changed the power hierarchy in some couple's relations and diminished men's say over their wives' lives. The following quotes reflect this point:

She finished some training related to her field of study and got a job. Her behavior changed shortly after. She wanted more independence to do things her way, return home whenever it pleased her, or buy a car. I asked her why a car? We do not need a car. We were living in downtown Montreal. She said she liked to go to work by her own car. I told her that I cannot pay for this one thing. I was the one paying the rent and more than half of the household expenses. I told her I could not pay for her car as well. However, she bought a car and paid for it herself. She got the car and went to work; so was lost the little respect she had for me. I could not ask her where she was or when she would come back. (Hadi)

It emerges from this account that the ex-wife's economic independence played a major role in the couple's separation. Such an outcome could be related to a woman's financial autonomy paving the way to her being more assertive about her individual aspirations, a challenge to the authority her husband used to exercise over her socioeconomic activities as the one primarily responsible for family issues and as its protector.

The analysis of the interviews reveals that women achieving social and sexual liberties in Quebec represented a major challenge to perceptions some men had of their role as the protector of the household. Generally, Iranian women have been identified as more resilient towards changes in social or sexual behaviors following immigration. Being raised in a socially conservative context that defines good women as chaste, preserving their sexual desires for their husbands and dedicated to the latter, Iranian women usually welcome social liberties met in their new environment. Absence of taboos around women having extra marital sexual relations and the fact that women are provided by better protection of their individual rights after immigration relieve Iranian women from the restrictions imposed on their 
sexual and social freedom (Darvishpour, 2002; Hojat et al., 2000; Mahdi, 1999; Shahidian, 1999). This topic was brought up by some participants. The latter believed Iranian women usually abuse such rights in Quebec or were manipulated by the illusions of freedom. It seemed the adoption of more social and sexual freedom opposed how these men perceived womanhood, dedicated to family goals and more modest in sexual behaviors. One man explained:

In Canada, as much as women are given liberties, they are expected to shoulder some of the social responsibilities. Iranian women, I'm afraid, do not have a good understanding of this point. They were in a socially limited situation, now their chains are broken, and they think they can experience liberty and independence, which is not a bad thing per se. However, for Iranian women, this is the source of their misunderstandings. Experiencing independence at what cost?! (Khosro)

Another one believed:

Montreal seems to be full of women (Iranian or otherwise) who have feminist tendencies and raise these illusions in women's minds that they might be even homoerotic...I know a lot of divorced couples where the woman under such impressions initiated the divorce process in spite of the husband's providing a stable financial situation... (Hadi)

Surely, men could gain some benefits from immigration too. Immigration could provide immigrants with opportunities to negotiate and redefine situations that are likely to enhance their position in the family and in the larger society (Froner, 1997), including some aspects of their gender identity (Farahani, 2012; Khosravi, 2009; Shahidian, 1999). As such, a few men interviewed for this study perceived immigration to Quebec as an important transition in their gender trajectory, relieving them from traditionally assigned duties associated with manhood, such as their role as the family protector and provider. The following quote illustrate this point:

...I am glad about my decision to immigrate because it has relieved me from many pressures. Of course, we are still officially married, but this does not make it any of my business where she is at any certain time. She comes home very late very often. And if we were in Iran, and she was seen walking alongside someone else, I would be asked a lot of questions; my honor and dignity would be under question. These things mattered to me in Iran. I do not care about it now. In such matters, the Iranian society exerts immense pressures on men... (Hadi) 


\section{Conjugality}

As an important part of family reconfiguration that followed modernity- meaning its democratization- conjugality is based on three main pillars: individualization of each member of the couple, equalization of relations, and intimacy between partners (Neyrand, 2016). The first concept highlights the individual's emancipation from traditional family ties and obligations. An outcome of modernity, individualization means greater freedom for every member of a couple vis-à-vis the responsibilities imposed on them by the traditional family order. As a result, the ideals of autonomy, self-fulfillment and intimacy have become new components of modern marital unions (Belleau \& Vézina, 2013; Neyrand, 2016). Nonetheless, the scope of changes is limited to certain parts of the world, mainly to Western societies. In societies where family life is guided by traditional ideals, dedication to collective family goals is still favored over individual aspirations, and pursuing individual desires are mostly viewed as selfish acts. This issue was frequently brought up by participants in this study. Most of them identified themselves as collectivistic rather than individualistic when it came to family life. As one man put it:

Here in family relations, people care more about their own selves, and this can be an upside at times. I had the same experience from living in Europe. What I mean is when one prioritizes himself, which is not that common in Iran. We spend so much energy on unimportant matters. In our culture, sometimes, sacrifice for the family is preferred to self-preservation. (Arsya)

Though most men explained that they did not favor the individualistic approach to marital life in Quebec, only a few of them perceived it as a negative influence on their personal couple dynamics. In fact, when discussing post-migratory changes lived in their marital relations, some participants in this study talked about their wives pursuing individual goals such as working or continuing education (which required husbands being more involved in household matters) rather than staying at home and taking care of children, as a cause for concern, contributing to conflicts in their union. For instance, one of the separated men voiced concern:

A couple of months after we immigrated to Canada, we had a kid, and our troubles began. She treated me differently. She behaved differently. And she decided to continue her studies. I had to take care of a two-month-old baby so that she could go to university and study... (Anoosh)

With individual autonomy and self-fulfillment becoming a value in modernity comes the ideal of equality between all citizens (Neyrand, 2016). 
However, the principle of modernity was not applied to family relations at the beginning, notes Neyrand (2016). In fact, the family sphere, particularly when gender relations were still run by assumptions taking nature and biology as a reference to legitimize the inequal positioning of men and women, led to the continuity of a binary that apportioned women with inside tasks and household matters while making work, public space, and authority as men's realm. Equalization of the position between men and women took place in the1970s, according to Neyrand; women achieving higher education, their paid work outside household, and the introduction of modern means of contraception gave women control over their sexuality and reproduction rights and prepared the way for more gender equality in the family. In traditional societies such as Iran, the cultural conceptions of gender relations are still highly embedded in biological differences between sexes, thus differential role distribution for men and women. Boys and girls are socialized into specific gender roles (Shahidian, 1999). Men taking part in household tasks could be negatively labeled as feminine. As one man explained:

My family has always been patriarchal, but I found out about it when I was around 16-17. Books that I read on the issues of gender relations had a great effect on me. I would tell my dad how he treated his wife and daughters was wrong and probably even unIslamic; it is very patriarchal. From the time I was 16, I would get into fights with my dad over such issues. My dad would get upset and would ask me to leave the room. He would tell me I was not a man yet... When my brother helped with the dishes, my dad would tell him he should be ashamed for doing such an unmanly chore. (Amin)

For many Iranian families, marriage is still regarded, borrowing from Neyrand (2016), as a symbiotic union. Complementarity of gender roles are prioritized over equalization of positions (Shahidian, 1999). Transitioning to a social setting governed by egalitarian principles of gender relations can challenge marital dynamics of the couples coming from such a social milieu (Mahdi, 1999). The issue of gender role division was frequently discussed by participants in this study when reflecting on changes experienced in their marital dynamics. As observed in their accounts, all participants were the ones primarily responsible for the family finances before immigration while their wives, even though working, were the ones mostly taking care of household chores. When asked what changes they had encountered in this regard after immigration, a few of them reported being more involved in household matters than before. As one man explained: 
Radical changes have taken place in our relations. Here, we do not have the arrangements we had concerning household chores anymore. Cooking, washing dishes and other tasks at home are shared. We have an unwritten contract between us, according to which each of us is responsible for some domestic tasks. This applies also to financial matters. Right now, it is mostly me taking care of the household's finances. Because of her work situation, my wife will have temporary contracts for a couple of years and I should probably work more. But we know that such a situation is temporary. (Mansoor)

Others talked about having a hectic working schedule or the wives' own interest in being the sole caretaker for inside matters as elements limiting their contribution to household chores:

I would like to help more at home. If the situation allows, I will do everything and there is nothing that I will not do at home. These days, I am very occupied at work. Thus, my wife is doing most of the household chores. I return home around 6 or 7 and she is doing much of the domestic jobs. (Arsya)

Asked how they perceived the ways responsibilities were assigned to men and women in Iran, a few participants reported that the traditional distribution of tasks was not a negative element per se, and that it could be viewed as an advantageous arrangement for women. Arya for instance expressed that:

The gender equity that exists here lessens the economic responsibilities delegated to men. This could sometimes threaten the stability of the family. When men do not have any responsibilities, women could feel more pressure... Things could get complicated with equality. Division of duties could weaken men's responsibilities, and this is not good. I think rules originating from tradition could be beneficial but have been badly applied in Iran. For instance, laws regulating dowry cause men to owe women. True that men get power from such laws, but they are always indebted to women. With power attributed to men comes responsibilities that protect the family... (Arya)

Changes in the patterns of gender roles were experienced by some participants. This was mainly because the wives of these men had started working in Quebec, thus contributing to family finances and being more involved in the financial decision-making processes, a role that was thus far 
undertaken solely by men. Such transformation was reported as an element occasionally causing some disagreements over financial expenditures. For instance, one participant explained that:

We have been experiencing changes in our financial responsibilities since we came here. Back in Iran, I took care of most economic matters. But now, because my wife works, this role has changed. I think it is normal to have such a change. When a woman works, she wants to have a say in household matters. And this is because, compared to men, women are not that much interested in taking risks. My wife wants to spend in a very precise and calculated way. I tell her not to worry, that everything is going to be alright. We have a joint account now and do not have any problems. However, we sometimes have disagreements over how to spend or if one of us has not taken care of a matter he/she was responsible for... (Mahmood)

For the separated men, however, changes in gender division of roles were perceived as the main trigger for marital conflicts. Being asked by their wives to split up the household matters while these men were still the ones primarily responsible for family's finances was reported as a major cause of difficulties experienced among couples:

...I saw it as an insult to share the domestic tasks. She was at home the whole day and was not working. So, she could take care of the household chores. However, it happened a lot that she did not do it. For instance, she did not wash the dishes for a couple of days and they remained in the sink all that time. (Anoosh)

As for intimacy and expressing affection, it should be noted that with the demise of traditional family arrangements and the prevalence of individual autonomy, they have become the core of union formation (Belleau \&Vézina, 2013). For Iranian men, this could be an area of challenge. They come from a culture where both men and women are expected to conform to certain genderspecific social behaviors (Shahidian, 1999); men as tough and introverted because they are the ones who face the hardships of the outside world, while women are expected to be more expressive about their feelings and good at handling household chores. The latter is embedded in cultural expectations of their role as wife and mother, explains Shahidian (1999). The question of intimacy and expressing affection for their wife was brought up by most participants. Some believed that they did not know how to be emotionally expressive towards women. This resulted in disputes between some couples. For instance, one of the separated participants indicated that this issue was one of the elements that had dismantled his marital relationships: "I did not know 
how to express myself to my wife. I am still not good at it with women in general. Our conflicts were partly due to financial problems, partly to emotional issues" (Hadi). Many participants believed that Iranian men are very conservative in terms of self-disclosure and expressing love. They favored the emotional expressiveness observed among Quebecois partners and showed themselves willing to introduce a change in this matter in their marital dynamics.

\section{Masculinity at a disadvantage}

A study conducted by a group of researchers in Quebec (Antonious, Lynhiavu, Dion, Antonious, Djaout, \& Gagné, 2008) reports that mass media's stigmatization of Muslim's cultural belonging weighs negatively on their daily life in the province. The authors argue that by frequently bringing up the issues of political violence in the Middle East, radical groups, social conservatism, or terrorist figures related to the region, and this mostly when deliberating on the question of accommodating Muslim immigrants in Quebec, some print media in the province have created a context in which violence is viewed as inherent to their cultures. "Islamité", and cultural differences form the centerpiece of their representations of Muslims, the latter having been consequently depicted as fundamentally different, and a threat to society. Antonius et al. (2008) state that the media's imprint on daily social interactions is inevitable when they take a position on a given group. By reducing Muslim immigrants to a single culture and essentializing the latter, the media have contributed to the uneasiness immigrants of Muslim origin and the host society feel in their daily social interactions (Antonius et al., 2008; Khosravi, 2009). Consistent with these findings, men interviewed for this study brought up the topic of being visible as immigrants in the Quebecois society, looked upon as strangers, or questioned over their national origin as elements making them feel uncomfortable in their social interactions within the new setting. For instance, one respondent said that "I have never tried to hide my nationality. But I really do not like when people here ask where I am from, or what my origins are. And I am frequently asked these questions..." (Mansoor). Another participant reflected that:

...In order to integrate, one of the most important conditions is how you are viewed in the host country or how you are judged. I feel like there is a lot of discrimination going on here. I feel like there is a bias towards people of Middle Eastern origin. And this upsets me beyond measure. We offer all our qualified contributions. But all in all, the reaction I usually get is a cold one. In my daily interactions, I feel this coldness. (Arsya) 
The $u s$ versus them dualism-stigmatizing men of Middle Eastern origin as traditional and violent, and women as submissive- has contributed to a rise in discriminatory behaviors against Muslims in Quebecois society (Antonious et al., 2008). Discrimination is defined as negative behaviors directed against members of a group one may maintain prejudices towards. Discrimination could express itself through fear, disdain, or hostility in the presence of the other (Bourhis, Montreuil, Helly, \& Jantzen, 2007). Being the target of discriminatory behaviors was frequently talked about by participants in this study. Such acts mainly occurred against them in the public sphere. One participant revealed that: "I was accosted by an elder woman and was called loudly an idiot. I believe it was because I visibly looked like an easterner" (Hadi). Another man said that: "I was spitted at several times in the street. I have been badly treated in public transport by some people. However, I have never reacted to such acts" (Arya).

Being exposed to discrimination in legal institutions was also a frequent theme discussed by the men interviewed for this study. A Canadawide study conducted by Statistics Canada and Canadian Heritage on ethnic diversity, integration, and discrimination in 2003 revealed that being discriminated against by police or in the courts was reported by $8 \%$ of anglophones and $12 \%$ of allophones elsewhere in Canada while it raised to $23 \%$ among anglophones (visible minorities whose maternal language is English) and 8\% of allophone populations in Quebec (Bourhis et al., 2007). In the same vein, recent studies on the question of discrimination and racism in Quebec show an increase in police discriminatory behaviors against visible minority groups, particularly indigenous peoples, Blacks, Asians, North Africans, Middle Easterners, and Latinos (Armony, Hassaoui, \& Mulone, 2019). For instance, concerning police stops, analysis conducted by Armony et al. (2019) reveal that between 2014 and 2017, racial groups, especially indigenous peoples and Arabs, faced more stops than white people. To address this issue of discrimination, the Quebec government constituted a group of specialists in 2020-Groupe d'action contre le racism - whose mandate was to outline a set of measures that will enable the province to combat racism in more effective ways.

Discussing their experiences of discrimination, participants in this study assumed that their visibility as men of eastern origin put them in a vulnerable position in the legal system. Such perceptions stemmed mostly from the negative impressions they thought existed in Quebec about Muslim men. One of the participants who had experienced police intervention in his marital disputes explained that:

In my experience, my ethnicity played a great role in court when going through the divorce and child custody process. During the process, I asked my lawyer why I am being judged this way. And 
he answered because you are a man from the East and your wife is in hijab. And the judge unconsciously thinks that you have pushed hijab on her, and consequently this lady could be under oppression. (Alireza)

Overall, two elements related to legal standards of the new social milieu were mostly singled out as the disruptor of family unions and as negatively affecting their position as man, and husband: police intervention in family matters and laws regulating divorce.

\section{Police Intervention}

Police mediation in family conflicts, though put in place to provide members with safety, is largely viewed as one of the interrupting elements of family life among immigrants, particularly those coming from societies with strong values attached to traditional family principles and its privacy (Thomas \& Znaniecki, 1984). In these societies, the larger family is the primary mediator when it comes to conflict between partners. Protection of marital unity is the first concern of such intervention. On the contrary, in societies where states' institutions are thought to meddle in family matters as an arbitrator among partners, the latter are usually "treated officially and unofficially as contesting parties..." (Thomas \& Znaniecki, 1984, p. 277). Thomas and Znaniecki explain that police interference in marital disputesmostly ending up with men being, often temporarily, transferred to prison so that the case is processed -could hurt the perception they hold on their "masculine dignity". The fact that strangers intervened in an issue considered a private matter, and that the man was put in prison and treated the same way as those charged with criminal acts, is considered as emasculating (1984, p. 279). Consistent with these arguments, for the men in this study, police meddling in family issues was considered an element creating a sense of insecurity for them in the family:

...The intervention of police on behalf of children is a good thing, as it should be... As for women, we should say that they are not weak as children are. They are adults and they think. If need be, they can get themselves into a police station. I believe there is a need for a legal system so that domestic violence is eradicated. But if this intervention is exaggerated and I as the husband do not feel secure, then I would rather leave that relationship. If for every trivial thing women call the cops on their husbands, this interferes with the sense of the security that a family should provide... (Moein) 


\section{Laws of Divorce}

As for the laws of divorce, it should be mentioned that men's unilateral rights to divorce have been reinstated in Iran since 1979 (Gerami, 2003; KianThiébaut, 2005; Moghissi, 2008). Mir-Hosseini's study (1993) on the laws of divorce in Iran reports that women's demands to divorce have been largely limited and contingent on meeting some conditions, such as the man being diagnosed with "impotency" or "insanity", incapable of providing for his family, condemned to long-term prison, married for second time while not having his first wife's consent, or being physically violent towards her. The latter is only recognized in cases judged as endangering her life. Of course, none of these terms are feasible without the husband giving his consent upon marriage, as indicated by Mir-Hosseini (1993). Immigration is a great transition in this matter for Iranian men and women. Some changes encountered in their family patterns after immigration allow Iranian women to leave un unhappy marriage. Most important among them are the absence of social taboos surrounding a divorced woman, absence of larger family interference when conflicts emerge among couples, having more access to socioeconomic resources to support themselves after separation, and having equal rights to initiate divorce (Darvishpour, 2002). One man commented:

So, one of the reasons why we got separated here was that my wife felt like no family of hers is around to ask why her relationship has gone bad. On the other hand, the negative aura around a divorcé is not a thing here in Quebec. Of course, number of divorces has skyrocketed in Iran recently, but it is still socially frowned upon... Here, nobody asks women if they are divorced or if they are homosexuals. And this absolves them from any social pressure they would have had in Iran. (Hadi)

Dowry (Mehrieh) could be another element complicating the process of divorce for immigrant men of Iranian origin. It is the payment transferred to the bride by the groom after their marriage. As described by Mir-Hosseini (1993), dowry in Iran is paid either in cash or property. Woman can claim it any time after the marriage is consummated. It could be regarded as a sum paid to women so that men could exert complete control over their independence or as means of providing women with some ways of financial support after divorce. The World Health Organization (WHO) defines such social practices as mechanisms of women's exploitation (2009). Mir-Hosseini (1993) argues instead that with men having unilateral rights to divorce and child custody, such a practice has been used as a tool by many women in Iran to negotiate terms of marriage and divorce. However, some respondents in this study believed it was men who were under pressure by the dowry since not only its existence was a heavy economic burden on their shoulders, but it also 
exposed them to being negatively evaluated in court when going through a divorce process in Quebec. Moreover, as noted by these respondents, dowry caused them a problematic situation because women had the rights to initiate divorce here in Quebec on the one hand and file a suit against them in Iran to reclaim their dowry on the other. They also thought it usually gives the court the impression that the marital relation is an arranged marriage and that the woman has been forced into. One of the separated men bringing up the question of dowry explained that:

In court, the woman says I have a dowry and my husband does not pay it. The judge asks what is a dowry, anyway? And the woman says it is the money indebted to her by him through marriage and the judge asks me what is this money about? So, how can I explain it to him? Should I say this was a guarantee so she would not think of divorce? And then the judge says if she did not have any rights to divorce that would mean she was in an arranged marriage. And I have to explain that this was not an arranged marriage. This was a sum of money that I owed her according to the marriage laws of Iran. And this lady can legally pursue it at any moment back in Iran. Such difference has not been defined in their legal system and .... A man might be judged in two systems, that of the origin and the host, and also lose all his privileges...(Alireza)

\section{Conclusion}

Masculinity like femininity is mostly about socially arranged practices through which individuals try to reflect their gendered selves (Connell, 2005). In Iranian society, masculinity is largely embedded in culturally rooted ideals of manhood as the protector and provider of the family (Mahdi, 1999). Keeping up with these conceptions of manhood after immigration- as noted in other studies exploring masculinities among Iranian immigrants (Farahani, 2012; Khosravi, 2009) - turned out to be challenging for some participants; difficulties met in the labor market, and thus the decrease in their social status, were reported by this study's participants as changes that had weakened their ability to keep up with their economic responsibilities. Many of them underwent a transition in their role as primary wage earners of the family following difficulties encountered in the Quebecois labor market. Such a shift was believed to negatively impact their self-esteem, since they could not adequately fulfill a role that was considered important to their responsibilities as man. However, most participants did not perceive the transition in the provider role as a disruptor of their marital union per se. In fact, immigrationas highlighted by Farahani (2012), Khosravi (2009) and Shahidian (1999)could mean an opportunity for immigrants to redefine certain aspects of their gender identity. Consistent with the findings of these studies, some 
participants in the present research expressed their flexibility towards changes in certain practices they viewed specifically apportioned to men in Iran, such as the provider role, thus sharing it with their wives. Despite this resilience, when asked whether women were equally responsible for the family economy, most men did not consider their wives as primary wage earners because meeting the family needs was still understood as a man's job.

Social liberties and sexual freedoms of women in Quebec were reported by some men as elements likely to disrupt couple's relations. This could be because such changes were closely tied with men's role as the protector and head of the family, the one allowing them to exercise control over women's activities and social relations. For instance, one of the separated participants (who was widely quoted in the section analyzing the protector role) felt that a decrease in men's responsibility as the protector was a loss for men, causing him to lose respect in their marital relations because his wife saw herself as no longer obligated to abide by her husband's opinions. While analyzing the conversations, the researcher noticed a recurrent theme emerging in the men's accounts of changes experienced in their role as the provider and protector: the redefinition of conjugal relations. The social scripts guiding marital life in the new setting, including the individualization of each member, the equalization of gender relations, and new ideas about intimacy, had impacted the marital union of some men. Gender relations were the most talked about topic by participants. The fact is that with their wives starting to work, returning to studies, or taking short-term training programs, and having access to governmental financial aid, on the one hand, and the difficulties encountered by these men during the process of professional integration, on the other hand, their role as primary wage earner of the family faded away. As well, with women being active in public life, men were expected to split up household chores. Moreover, with the new financial resources likely to help them gain some economic independence, women became more involved in the household decisions, such as economic expenditures. As it could be noted in quotes provided in the analysis of the findings, some men perceived these changes as a positive influence on their marital relations, while a few of them reported negative outcomes for their marriage. Life course being a contextual phenomenon, a shift in social milieu means that the socially arranged behaviors, attitudes, and roles used so far for the unfolding of trajectories need to be defined, reconstructed, and negotiated in the new setting so that life course can function (Carpenter, 2010; Elder et al., 2003; Furstenberg, 2003; Gaudet, 2013; Macmillan \& Copher, 2005; Mayer, 2004; Thomas \& Znaniecki, 1984). Put in this perspective, failing to reconstruct their masculinity in the face of changes regarding marital relations, some participants- mostly the separated ones- experienced the disruption of the conjugal trajectory; their marriage could no longer function with their wives 
being open to transformations expected to enhance their position, while men chose to hold on to the old traits. With their marriage broken, a move to new social settings thus appeared to be a turning point in their marital trajectory.

The main concern for most men in this study-as in Khosravi's research (2009)- seemed to be their visibility as immigrants with Middle Eastern roots. Immigration to Quebec was believed to have put them in a disadvantageous position as men. They thought being visible as Middle Eastern men had resulted in them being treated as strangers in daily social interactions, thus making them feel unease in the new social milieu. This visibility was believed to make them vulnerable in the face of the legal standards in the host society, as well. The legal standards regulating family laws in Quebec were perceived by most respondents as affecting them negatively on an individual and family level. With family being considered a private matter and them being delegated as its protector, states' interference in family affairs meant strangers being involved in their privacy, on the one hand. On the other hand, the way police treated them following a family dispute (e.g. being cuffed in kids' presence)borrowing from Thomas and Znaniecki (1984)- hurt their "masculine dignity".

\section{Potential Implications for Social Policies}

This study contributes to a better understanding of masculinity as a trajectory. It is a trajectory because like any other pathway of an individual's life, masculinity is a continuous process of rethinking certain social scenarios, such as the ones regarding gender roles and relations that are used as guidelines to develop gender identities. It is also a situated act evolving in a context that has already established some models of masculinity or femininity as socially valued; the model of men as provider or protector in Iranian society, physically strong and emotionally introverted. Finally, masculinity is a trajectory because it is marked by transitions (in roles, statuses, and positions) that are perceived as a positive change by some immigrant men (e.g. feeling less socioeconomic stress since they are liberated from the traditional duties apportioned to them as men or becoming emotionally more expressive towards their wives because they are no longer labelled as feminized) or a negative shift by some others (e.g. losing authority at home, and, hence control over women's individual and social activities). Overall, the transitions and changes experienced by participants in this study on an individual and marital level confirm that immigrant family is a malleable phenomenon whose form and content can adjust to new situations when the context changes (Froner, 1997). The difference remains in the scope of the changes from one family to another and one member to another.

For many new immigrants, immigration is a strategy aimed at providing a better socioeconomic future for all the family members (Vatz 
Laaroussi, 2003). However, the challenges encountered along the process of integration into the new social setting could hinder the achievement of such family goals; difficulties in finding a qualified job, confusion about marital roles and responsibilities as well as the family laws of the host society are the main challenges faced by men in this study. As discussed earlier in this paper, a more difficult integration pathway for men has been reported by literature on immigrant families of Iranian origin (Darvishpour, 1999, 2002; Mahdi, 1999; Moghissi \& Goodman, 1999; Shirpak et al., 2011). Based on these studies and the findings of the present research, some initiatives are needed to implement more effective integration policies, easing the process of readjusting life in the new social environment.

a) As debated before, even though most participants in this study come from the economic class of immigration, many experienced difficulties in finding jobs commensurate with their expertise. The fact is that Quebec's immigration policies are above all strategies to ensure a better social and economic growth. This objective could be more easily achieved if the province benefits from the skills of its new residents. This makes essential a faster professional integration of the newcomers. Achieving this objective poses the challenges of redefining the present policies of economic integration and of defining new measures that address the obstacles to a faster recognition of foreign credentials. Such a change could shorten the period of professional transition undergone by many new immigrants, hence the impacts of a precarious economic situation on their marital life.

b) Police intervention in family matters was a cause of concern for participants in this study. For immigrants of Iranian origin, as for many others coming from Asian, Middles Eastern and North African societies, family affairs are regarded as private. In case of conflicts, it is the primary family members who intervene to prevent the breaking down of the marriage. Police interference can create a sense of insecurity for immigrant men coming from such societies (Thomas \& Znaniecki, 1984). Some participants mentioned that if they do not feel safe because of the police interference in conjugal disputes they would rather get out of their marital relationship. It seems that for situations of marital conflicts, long before the police have the mandate to intervene, there should be some mediatory processes preferably managed by individuals who have done mediation or social work in that particular community.

c) A high percentage of participants in this study expressed concern over their own lack of practical, legal knowledge of how familial disputes are treated by Canadian law or what exactly constitutes their rights or prerogatives. It is the contention of this study that a governmental 
service is needed which provides essential information based on the needs of newcomers who may not know their constitutional rights and boundaries regarding a range of social issues. Such a service could be provided online, through phone, or in-person.

\section{Limits of the Study}

Given the increase in Iranian immigration to Canada and Quebec, more studies of this community are needed to provide insights on challenges faced by members of immigrant families, how they reconstruct their trajectories, and the way changes impact their family relations. This study is based on 19 life stories of men living in Quebec. Thus, it cannot be assumed to be the reality of all immigrant men of Iranian origin. Certain limitations of the study should be noted such as a small research sample, the majority of whom came from the middle or upper classes, were university-educated, and were admitted under the economic immigration category. The fact that all participants in this research hold university degrees could convey the idea that these are voices of educated people, and thus not an adequate representation of the family patterns maintained by many Iranians. In this regard, it should be explained that this proportion of university-educated participants in the sample is not surprising, given that Quebec has a point-based immigration system that selects its immigrants mainly according to their education, work experience and language skills. The other point that should be taken into consideration is that there is not necessarily a correlation between level of studies and prevalence of modern family behaviors. Some individuals coming from the middle or upper class in this study adhere to what has been defined in this paper as traditional family patterns. Despite all these limits, the heterogeneity of the sample-corresponding to categories of age, arrival year, social milieu, immigration status, level of studies and marital status- represents, to a great extent, the diversity of marital experiences among Iranian immigrants finding themselves in the same social world, that is the integration into the mainstream family life of Quebecois society.

\section{References:}

1. Davey, E., Borton, J. \& Foley, M. (2013). History of The Humanitarian System Western Origins And Foundations, An Introduction to Humanitarian History, Overseas Development Institute, HPG Working Paper, London, p.1.

2. Dornbusch, R. \& Fischer, S. (1998). Makro Ekonomi (S.Ak ve ark. Çev.), (First Ed.), Mc Graw Hill-Akademi, İstanbul.

3. Eğilmez, M. (2019). The Economy of Turkey, Remzi Bookstore, İstanbul. 
4. Kaçanoğlu, M. (2019). “Amartya Sen's Development Perception: Post-Development Approaches Based Study, Doctorate Thesis, Gazi University, 2019.

5. OXFAM (2020).The Humanitarian-Development peace Nexus, http://www.oxfam.org.

6. Özkul, A.Ö., Dincer, H., \& Hacioglu, U. (2015). "Regional Economic Integration and the Global Financial System" Development Agencies, Grant System And Financial Support For SME's In Turkey, IGI Global, 1st ed., Pennsylvania, p.21.

7. Rysaback-Smith, H. (2015). "History and Principles of Humanitarian Action" Emergency Medicine Association of Turkey, Kare Publishing.

8. Sen, A. (1999). Development with Freedom, transl. Yavuz Alogan, Ayrint1, İstanbul, 1999, p.17-18.

9. Tronc, E., Grace, R., \& Nahikian, A. (2019). "Realities and Myths of the "Triple Nexus" Local Perspectives on Peacebuilding, Development, and Humanitarian Action in Mali" Humanitarian Action at the Frontlines: Field Analysis Series, Harvard Humanitarian Initiatives, p.25.

10. Turhan, Y. (2019). "The Role Of Faith-Based Non-Governmental Organizations In Turkey's Humanitarian Aid Policy And Practice" Doctorate Thesis, Middle East Technical University.

11. Yeldan, E., Taşçi, K., Voyvoda, E., \& Özsan, M.E. (2013). "Turkey On Her Way Out Of Middle-Income Growth Trap" Vol.1., Istanbul, TURKONFED.

12. http://www.3rpsyriacrisis.org/ (06.05.2020).

13. https://tr.wikipedia.org/wiki/\%C4\%B0zmir_\%C4\%B0ktisat_Kongres $\mathrm{i},(02.05 .2020)$.

14. https://ekonomihukuk.com/buyume-kalkinma/kalkinma-teorileri, (02.05.2020).

15. https://reliefweb.int/sites/reliefweb.int/files/resources/WFP\%20Syria \%202020\%20Annual\%20Country\%20Report\%20\%20PDF\%20version.pdf, (03.06.2020). 